\title{
Different Perspectives to Analyze the Penal Justice System in Function of Crime Control from Professionals of Social Sciences
}

\author{
MSc. Marinela Sota \\ University of Tirana, FSS, \\ Department of Social Work and Social Policies \\ E-mail: marinelasota@yahoo.com
}

\section{Doi: 10.5901/mjss.2013.v4n4p249}

\section{Abstract}

Penal justice system is made of many agencies that take decisions, agencies of execution of penal decisions, so it's difficult to understand immediately the relation between them and their position regarding the law itself. This article unifies the ways of looking at the penal justice system in its wholeness and gives different perspectives to analyze it. Different parts of penal justice system raise to us important questions so to have a view of all parts of it, even those hidden, we need to see it from different perspectives. Penal justice system might be seen from different perspectives: its structure, police role, penal decisions phase, common policies of crime control of different institutions or penal procedures foreseen in the penal legislation. To understand penal justice system we need to be familiar with penal legislation, institutional practices but also to know the socalled "system models" and management styles which are some of more suggested perspectives to be used by social sciences professionals.

Key words: penal justice, penal legislation, institutional practices, system models, crime control.

\section{Introduction}

Penal justice system is made of many agencies that take decisions, agencies of execution of penal decisions, so it's difficult to understand immediately the relation between them and their position regarding the law itself.

This article unifies the ways of looking at the penal justice system in its wholeness and gives different perspectives to analyze it.

Different parts of penal justice system raise to us important questions so to have a view of all parts of it, even those hidden; we need to see it from different perspectives.

Penal justice system might be seen from different perspectives: its structure, police role, penal decisions phase, common policies of crime control of different institutions or penal procedures foreseen in the penal legislation.

To understand penal justice system we need to be familiar with penal legislation, institutional practices but also to know the so-called "system models" and management styles which are some of more suggested perspectives to be used by social sciences professionals. The aim of presenting different perspectives to see our criminal system is not to criticize which in not an excluded action for the professionals in or out the system, but our aim is to raise the possibilities to understand it, to expand the ways of seeing it in the light of different perspectives and the ways it's functioning. For example, the system might be seen as a production line that begins with the charges and ends with the court's decision producing charged persons, sentenced persons, imprisoned persons and sentenced persons in the community. This process in its routine is characterized by the production of thousands of people that admit the guilt or not, are considered guilty by the court, been sentenced, finish the sentence and they are out in the society again, quite often without the necessary the sources and the skills to stay out of crime.

On contrary, the system may be understood as a process that doesn't develop in an "easy" way but in the process there are trials, evidences, witnesses, etc. Both ways we presented the criminal system might be happen, but each of them raise different questions, have different implications and effects, even when the decision is the same.

\section{Perspectives for the system of criminal justice}

Different parts of criminal justice system raise to us different important questions, the need to understand the system as whole and specific parts of it, the need to find answers for delicate questions and suggest changes that improve the system, put us in the position of finding different perspective to look at it. Criminal justice system may be seen from 
different perspectives: its structures, police role, decision-making phase, common policies of crime control from different institutions or the foreseen procedures in the criminal procedures legislation.

The analyses that may be employed vary according to the issues considered important from the recruiting of police employees to the reasons of imposing imprisoned sentence for specific criminal felonies. If we want to focus in the roles of different actors in the process issues as recruiting of judges or Probation Services 'employees are unimportant, but if we want to see how is the execution of the law in the procedural elements such as: arrest, charges, sentence, probation, we should focus on issues as: trend of cases judged in other levels of court system, control in the institutions as police, courts, etc.

Each perspective to analyze the criminal justice system has its advantages, but it's very important that the system must be seen as a whole and not fragmentized because if we see selected parts then it's the risk of losing the focus on the main aim and the objectives of crime control.

\section{Criminal Legislation}

In order to understand the criminal justice system we must look at criminal legislation, this requires familiarization with the legislation, different levels of the courts, cases. Knowing criminal legislation doesn't mean to know the laws in all words because they are changing and improving all the time but this mean to understand the legislation and to understand the impact that court decisions of different levels have on the system. Knowing and understanding the principles of legislation, the ways of case appealing, the hierarchy of courts and theirs jurisdiction, the mission of different subjects in criminal proceeding, are important elements needed to be known by social workers during their practice in the system.

The analyzes of the system based on the legislation and court decisions have the advantages of putting in light issues that are debatable not only for the professionals in the criminal justice system but even for the society.

Analyzes based on the constitutional principle of presumption of innocence till is decide differently by court, analyzes about the legislation and the court decisions make us understand and appreciate the democratic principles that put the limit not to be overcome by law, subjects, media, society itself, in the criminal justice system.

Many persons that are sentenced have admitted the guilt about the felony they are charged but the system must guarantee a legal process which has standards about the evidences and all criminal procedures applied by the police, prosecution and the court.

Setting up the principles and the prescription of detailed procedures could be developed by the police or prison administration guarantee their activity in accordance with Human Rights, so in one hand this define the legal ground where they are legitimate to work on and on other hand it restricts them to stay on law limits.

\section{Institution Practices}

A major approach to the understanding of criminal justice involves the observation of daily practices of police, prosecutors, judges, prisons staff, defense lawyers and other participants in criminal justice process. This approach is important to understand and evaluate if the exercitation of the authority, the practices of the institutions are in accordance with law enforcement. Institution practices approact is focused on the criteria used by the police in the cases investigation or arresting the suspects, it analyzes the charging decisions of prosecutors, sentencing practices of judges, describes the classification of the inmates, their disciplinary practices, and application of the criteria for the release on the parole.

In dealing with much information we tend to order and classify it according to a specific principle. The same is true to understand the criminal justice. One of the techniques of classification of the information in order to understand the meaning of the whole system is application of "models". Such a technique brings light in different aspects of criminal justice system. Herbert L. Packer (Packer,1968) suggests that two models can be applied to understand the system: crime control model and process model.

Crime control model- This model describes the criminal justice system as a system built to procede in a fast way the guilty persons. Packer comments:

\footnotetext{
"The value of the system that underlines crime control model is based on the preposition that the repression of criminal conduct is the most important function of criminal process. The failure of law enforcement to control and bring before the system the criminal conduct is viewed as leading to the breakdown of the public order and so in the disappearance of an important condition of human freedom. The model, in order to operate successfully must produce a high rate of the conviction in a context where the sources are limited. To illustrate this model it comes in our mind a system that works without no rest from the employee in the police station that take the case, the police officer who does the investigations, the prosecutor who do charges and brings the case to the court, the judges that take final decision and 
gives us a closed file. The criminal proceeding viewed in this model might be alike a screening process, where each phase- investigation before the arrest, arrest, investigation, preparation to the court, trial, the conviction-includes a set of procedures, whose success is on moving the process ahead."

Crime control model is a description of how criminal proceeding in the most cases operates and Packer correctly outlines that such a model is based on "presumption of guilt" not as a juridicial norm but as a operational prediction of outcome.

\section{Proccess Model}

This approach offers a new perspective similar to an obstacle course. Each phase of criminal justice according to this model is designed to present obstacles that impede the accused to be passed on the further stage. Process model outlines the importance of the formal process of gathering the evidence to contradict the charge and requires that the evidences against the accused to be heard by a impartial and independent court. The accused should have the full possibility to contradict the evidence of prosecution.

We must understand that the models don't differ a lot in their main objective- control of crime- but they differ in their methods and in kind of issues and short-term objectives. Are different models just alternative ways to proceed different cases? Packer (1968) believes that essential differences between them are related to a conflict between the desire for efficiency (crime control model) and the idea of primacy of the individual and the limitation of the official power (process model).

Medical model - This model applies the processes of medicine that means that accused is viewed as "sick" or "socially illadjusted", police is viewd as "crisis intervention" or "emergency", prosecutors and judges are viewed as "diagnosticians" and "prescribers" and prison staff as "treaters". The accused is seen in this model as "sick" or "well" as in the medical process.

Medical model is criticized because is making the assumption of pathology about the offender. This model doesn't consider that in the medical profession the causes of different illness are admitted generally by the professionals but in justice professional is lacking the consensus for the causes of crime in general or even for a specific crime.

The application of models in the criminal process has advantage of viewing the whole process but has also the risk of overgeneralization.

\section{Management style}

Except of models of criminal process, there is another general approach that is looking at criminal justice issues by comparing managerial behavior within criminal justice agencies. This technique is similar to the technique used by criminologists to classify types of offenders- the occasional property offender, sexual offender, member of gangs or organized crime, etc- but this techniques is focused on the participants in the criminal process and not to the offenders. Based on different techniques, this approach asks questions as: Can individual or organizational behavior and styles affect in the changes of practices of law application in different agencies, can individual and organizational behavior and styles affect the decisions of prosecutors and judges? As an application of certain model, the study of management style is a effort to generalize because the individual characteristics and actions are relevant if they can be group within some collective patterns.

Police management styles- James Q. Wilson (1999) after conducted a research about the management styles and the changes that they are bringing in the activity of the police, listed three management styles that affected in a significant way the methods and the patterns of actions:

Watchman police agencies - focused primarily on the keeping order in the community, rather than the correct exercising of the law.

Legalistic police agencies- focused on law, detaining lots of suspects, using correctly the power of arrest.

Service agencies- very much presented in the community, intervening frequently to solve the disputes, acting informally and arresting as the last solution.

Wilson related police management styles to the types of communities, agency organizational patterns, leadership and the political context of communities, for example service agencies are more found in homogeneous middle-class communities. 
Correctional management styles- Categorization of the ways that employees fulfill their roles within the agencies depends on variation of typing agencies, as Wilson did with the police. For example, Ohlin, Piven and Pappenfort (1998) identify three major types of probation officers:

1. Punitive officers - attempt to exercise their role into conformity with their moral standards.

2. Protective officers - position themselves between the protection of the offenders and the protection of the community.

3. Welfare officers - main goal is the improved adjustment of offenders.

Categorization of above employees is related to the applied practices during the supervision of the offenders, so for example punitive officers focus on the control of the offenders and neglect the support to the offenders to change.

In the same line with the categorization of Wilson, O'Leary\&Duffee identified four types of correctional policies that determine the emphasis that correctional agencies give to changing offenders, protecting the community from offenders or changing opportunities for inmate reintegration in the society:

Reform correctional institutions - are oriented to community protection with prisons that impose "good behavior" to the offenders.

Rehabilitative institutions - focus to change the personality characteristics of offenders mainly by clinical interventions.

Restraints institutions - focus more on security and preventing the escape of offenders.

Reintegrative institutions - focus more on collaboration with the community, that are enforced by using community resources, stressing the need for the adjustment of offenders during the sentence.

\section{Aims of crime control}

The complexity of criminal justice processing is determined by the fact that system has multiple purposes. Although its primary aim is the control of crime and the maintenance of public order, the system is built on the different beliefs and expectations how it can functions better. Some expectations as: control is achieved through the punishment of violators are considered as old and are based on the philosophic justification that human being is sin able. Other expectations as rehabilitation of the offenders are products of social sciences based on the concepts as behavior, personality and change.

We can say that different expectations about the aims of crime control affect the process in the criminal justice.

\section{Crime control has these functions:}

1. Punitive function

2. Deterrent function

3. Community protection function

4. Corrective function

Punitive function - There is no doubt that the primary aim of criminal justice is the punishment of the offenders. In the meaning that we have nowadays is that the sentence is the final step of the process. Punishment has another aim also that is to deter the potential violators sending the message that who will violate will pay.

The application of the sentence to the offenders is in proportion with the crime and the damage caused by the offence.

Deterrent function - One of the functioning of the crime control is to deter the potential violators from committing crimes. The use of examples as; those who commit crimes are caught and sentenced, show of force is more important than the use of force, have more effects on deterrence.

Reforms in 60-70 last years in criminal justice were focused in the adjustment of the sentence with the characteristics and different circumstances (personal, familiar, social) of the offender.

Community protection function - This function is a general public expectation for the criminal justice system. In fact, the main aim of the imprisonment through the limitation of physic liberty is to make them unable to commit other crimes and to protect the community in final. Not only the imprisonment has the aim of community protection but even other legal actions such as arrest, bail, etc aim to prevent the suspected offender to commit other crimes with the final result of community protection. The correctional system aim to fulfill this function of crime control, so for example, the impose of specific conditions by the court during the probation, treatment program during the imprisonment, have as aim to protect the community from crime. The whole system seeks to set the balance between the needs and the desires of the offender (suspected or sentenced) and the concerns regarding the protection of the community or public. 
Corrective function - From the institutions of execution of penal decisions is expected to change of the offenders, rehabilitate or at least to prevent them make worse. So the activity of these institutions, programs applied, treatment of the prisoners is oriented to create such behaviors to the offenders that are not in conflict with law. More than ever before the institution of execution of penal decisions are setting up and implementing programs that aim to achieve the rehabilitation of the offenders during the sentence and their successful reintegration in the community supporting them with community resources.

Although this function is attributed more to the institutions as prisons or probation service, it's becoming part of the public debate that other institutions within and outside the criminal justice system have a role to play in this regard. The way how is proceeded the arrest, the attitude and behavior toward the suspect, the interrogation during the investigation, treatment with respect and according to the law, are affecting the negative attitudes of the offenders or in contrary create positive attitudes toward the police, the public authorities, etc.

\section{Conclusion}

Criminal justice is a system that is made of different institutions that execute penal proceedings or penal decisions and might be difficult to understand at once the relation between them and in relation with the law.

This article suggests a number of different perspectives to view and analyze criminal justice system.

Different parts of criminal justice system raise to us important questions and in order to understand the system as a whole, find the answers to delicate issues or suggest improvements to the system, we need to view the system from different perspectives.

The criminal justice system can be viewed by these perspectives: criminal justice system structure, the police role, decision making phase, common policies to control crime, or criminal procedures foreseen by law in criminal proceeding.

To understand the criminal justice system we need to know criminal legislation. Knowing and understanding the criminal legislation, its principles, the appealing cases, hierarchy of the courts and their jurisdictions, the mission of different institutions in the criminal justice system, are important elements in the practice of social work.

The institutions practices approach is focused on the criteria and practices employed by the police in investigation or arrest, this approach analyzes the process of charges by the prosecutors, the practices of sentence making by the judges, describes classification of the offenders, disciplinary practices and application of parole.

The application of "models" for the whole criminal justice system is a suggestion that comes from different authors because it brings as a result the outline of different issues, so we can say that the crime control model, process model, medical model and management styles are models that can be used to view and analyze the criminal justice system.

\section{Bibliography}

Packer.L.Herbert, 1968, Limitet e Dënimeve Penale (The limits of Penal Sanctions) Stanford University Press.

David Duffee, Explaining Criminal Justice, Cambridge, Mass: Oelgeschlager, Gun and Hain, 1981.

Vincent O'Leary and David Duffee, "Correctional Policy: A classification designed for change".

James Q. Wilson, Varieties of Police behavior (Cambridge, Mass: Harvard University Press, 1968.

Lloyd Ohlin, Herman Piven and Donald Pappenfort, "Major Dilemmas of the Social Worker in Probation and Parole, National Probation and Parole Association Journal 2 (1956) 
